\title{
CURB-TO-BARRIER FACE DISTANCE VARIATION IN A TB51 BRIDGE BARRIER CRASH TEST SIMULATION
}

\author{
KRZYSZTOF WILDE ${ }^{1}$, KAZIMIERZ JAMROZ ${ }^{2}$, DAWID BRUSKI ${ }^{3}$, \\ MARCIN BUDZYŃSKI ${ }^{4}$, STANISLAW BURZYŃSKI ${ }^{5}$, JACEK \\ CHRÓŚCIELEWSKI ${ }^{6}$, WOJCIECH WITKOWSKI ${ }^{7}$
}

\begin{abstract}
This paper addresses the problem of road safety regarding barrier placement as relative to the curb. A short summary of existing regulations is presented. Numerical simulations using the explicit finite element system LsDyna are shown. In the analysis, variable distance between the barrier and the curb is assumed. The obtained result reveals that the distance has little impact on the working width of the barrier.
\end{abstract}

Keywords: crashtest, bridge barrier, bus, simulation, LS-DYNA

\section{INTRODUCTION}

Poland's road safety issues have become the subject of research projects covered by the research program of the National Center for Research and Development and the General Directorate for

\footnotetext{
${ }^{1}$ Prof., DSc., PhD., Eng., Gdańsk University of Technology, Faculty of Civil and Environmental Engineering, ul. Narutowicza 11/12, 80-233, Gdańsk, Poland, e-mail krzysztof.wilde@wilis.pg.gda.pl

2 Prof., DSc., PhD., Eng., Gdańsk University of Technology, Faculty of Civil and Environmental Engineering, ul Narutowicza 11/12, 80-233, Gdańsk, Poland, e-mail kazimierz.jamroz@wilis.pg.gda.pl

${ }^{3}$ MSc., Eng., Gdańsk University of Technology, Faculty of Civil and Environmental Engineering, ul. Narutowicza 11/12, 80-233, Gdańsk, Poland, e-mail dawid.bruski@wilis.pg.gda.pl

${ }^{4} \mathrm{PhD}$., Eng., Gdańsk University of Technology, Faculty of Civil and Environmental Engineering, ul. Narutowicza 11/12,80-233, Gdańsk, Poland, e-mail marcin.budzynski@wilis.pg.gda.pl

${ }^{5} \mathrm{PhD}$., Eng., Gdańsk University of Technology, Faculty of Civil and Environmental Engineering, ul. Narutowicza 11/12, 80-233, Gdańsk, Poland, e-mail stanislaw.burzynski@wilis.pg.gda.pl

${ }^{6}$ Prof., DSc., PhD., Eng., Gdańsk University of Technology, Faculty of Civil and Environmental Engineering, ul Narutowicza 11/12, 80-233, Gdańsk, Poland, e-mail jacek.chroscielewski@wilis.pg.gda.pl

7 DSc., PhD., Eng., Gdańsk University of Technology, Faculty of Civil and Environmental Engineering, ul. Narutowicza 11/12, 80-233, Gdańsk, Poland, e-mail wojciech.witkowski@wilis.pg.gda.pl
} 
National Roads and Highways under the title "Development of Road Innovations (RID)". This initiative is the first comprehensive enterprise of ministries of science and infrastructure with such great potential for reducing the risk of injury or death in traffic. One of the research projects carried out within the framework of this program is the RoSE project, carried out by the research team at the Gdańsk University of Technology. The aim of this project is a comprehensive analysis of the functioning of the various systems of protection of vehicles on the road in the event of the sudden loss of control by the driver and various types of supporting structures installed on the roads as well as engineering objects, using the results of crash tests and numerical simulations. One of the important topics of research is to identify their functionality and propose innovative solutions for incorporating bridge barriers.

Since full-scale in-situ crash tests are expensive and performed only in specially designated areas, numerical analysis is commonly used to conduct verification and validation of these variables to then carry out parametric studies of crash tests. The Ls-Dyna (finite element method code) is commonly used in this area, in order to build detailed models of vehicles (eg. papers by Kwaśniewski and Wekezer $[1,2]$ ) and perform a wide range of crash test simulations under various conditions (eg. [3,4]).

\subsection{CURB AND BARRIER POSITIONING GUIDELINES}

There is nothing in Poland's guidelines for national roads [5] about the recommended distance between the curb and barrier face. The guidelines only include the following recommendations for curbs [5]:

- the recommended minimum height for curbs on the bridge pavement with a safety barrier should be $(8 \div 10 \mathrm{~cm})$ above the roadway so that if a vehicle drives over the curb, the impact will not be too strong,

- for a calculation speed of $\mathrm{V}_{\text {obl. }}<50 \mathrm{~km} / \mathrm{h}$ to ensure restraint curbs must be $15 \div 20 \mathrm{~cm}$ high with a balustrade.

In addition, the heights of curbs accompanied by barriers are covered in the Technical Conditions [6], according to which a curb should be above the roadway level if:

- there is a barrier between the roadway and pedestrian or service pavement or a cycle path not less than $0.08 \mathrm{~m}$ and not more than $0.14 \mathrm{~m}$,

- if it is next to a barrier fixed on the edge of the structure - not less than $0.14 \mathrm{~m}$ and not more than $0.18 \mathrm{~m}$. 
the guidelines of the ZDW Road Authority in Katowice [7] in order to help specify the appropriate distance between the barrier face and the curb for structures or roads where a pavement and curb structure exists together. The distances should be as follows:

- $\geq 0.5 \mathrm{~m}$ (case a),

- $>0.2 \mathrm{~m}$ if the distance between barrier face and traffic lane edge is min. $0.5 \mathrm{~m}$ (case b),

- $\leq 0.2 \mathrm{~m}$ if the minimum distance between traffic lane edge and barrier face is $-1.0 \mathrm{~m}(0.75$ $\mathrm{m}$ for $\mathrm{L}$ and $\mathrm{D}$ class roads) (case c).

An analysis of the guidelines and road safety standards in other countries have shown that the distance between the barrier face and the curb differs from country to country.

Czech guidelines [8] suggest a distance between barrier face and curb ( $0.15 \mathrm{~m}$ high) between 0.1 and $0.2 \mathrm{~m}$. The USA's NCRHP 537 report [9] shows a variety of barrier face-to-curb distances and suggests a specific distance between the barrier face and the edge of the road - depending on the type of curb and barrier. The majority of these cases have a distance of $0.0 \mathrm{~m}$ between the barrier face and the curb. Other possibilities include $0.15 \mathrm{~m}$, ranges from $0-0.23 \mathrm{~m}$, or values in the order of several meters. The recommended distances between barrier face and curb in Australia's guidelines are [10]:

- $0.3 \mathrm{~m}$ for wire rope barriers,

- $0.2 \mathrm{~m}$ for steel barriers (under normal conditions) and $0.0 \mathrm{~m}$ if there is no space,

- $0.0 \mathrm{~m}$ for concrete barriers (no curb where concrete barriers are used).

Norway's guidelines [11] suggest that no recommendations are needed for the analyzed distance if the curbs are low (maximum height of $85 \mathrm{~mm}$, with a grade up to $35 \mathrm{~mm}$ from the side of the road). There are no recommendations regarding the use higher curbs.

\subsection{BARRIER'S WORKING WIDTH}

Working width $\left(w_{N}\right)$ is one of the parameters used to describe a barrier's deformation in a crash test in a quantitative manner. Working width is defined as the lateral distance between barrier's face from the side of impact to the extreme position of any part of a barrier during a crash test [12]. In the case of significant deformation of a vehicle, working width should be measured to the most displaced part of the vehicle. Levels of working width are shown in Table. 1.

In our study via numerical calculations, several values of distance between barrier face and curb are analyzed, namely $a \in\{0 ; 50 ; 200 ; 400 ; 600 ; 800 ; 1000\} \mathrm{mm}$ (see Fig. 1). Table 2 consist of 
information, whether each analyzed in present paper value of $a$ parameter fulfills mentioned before guidelines.

\section{NUMERICAL MODEL}

\subsection{VERIFICATION AND VALIDATION}

As discussed by Sargent [14] all simulation models, as those for example generated and used in FEM, are nowadays very popular supporting the process of decision making. It is commonly

Table 1. Levels of working width [12].

\begin{tabular}{|c|c|}
\hline Classes of working width levels & Levels of working width, m \\
\hline$W 1$ & $W_{\mathrm{N}} \leq 0,6$ \\
\hline$W 2$ & $W_{\mathrm{N}} \leq 0,8$ \\
\hline$W 3$ & $W_{\mathrm{N}} \leq 1,0$ \\
\hline$W 4$ & $W_{\mathrm{N}} \leq 1,3$ \\
\hline$W 5$ & $W_{\mathrm{N}} \leq 1,7$ \\
\hline$W 6$ & $W_{\mathrm{N}} \leq 2,1$ \\
\hline$W 7$ & $W_{\mathrm{N}} \leq 2,5$ \\
\hline$W 8$ & $W_{\mathrm{N}} \leq 3,5$ \\
\hline
\end{tabular}

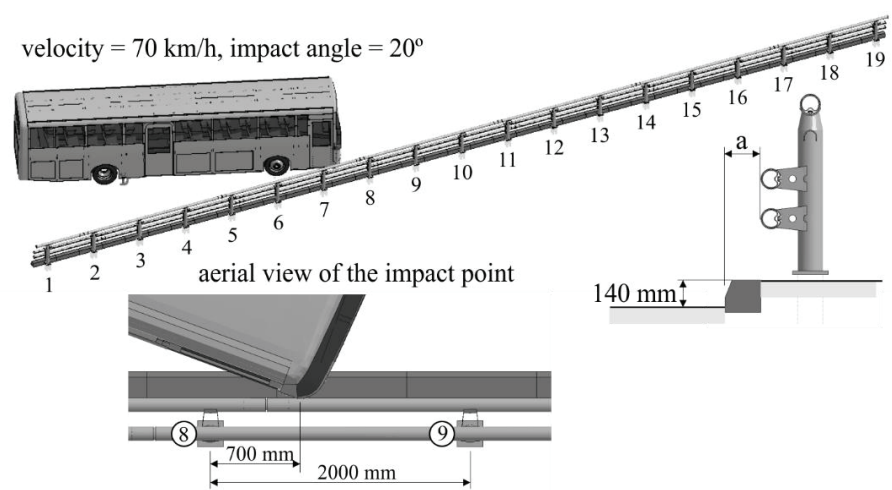

Fig. 1. General view of the crash test, aerial view of the impact point, definition of parameter $a$. 
Table 2. Analyzed values of a and compliance to recommendations of each guideline.

\begin{tabular}{|c|c|c|c|c|c|c|c|}
\hline $\begin{array}{c}a \text { - barrier face } \\
\text { to curb distance }\end{array}$ & {$[7]$ case a } & {$[7]$ case $\mathrm{b}$} & {$[7]$ case c } & {$[8]$} & {$[9]$} & {$[10]$} & {$[13]$} \\
\hline 0 & & & yes & & yes & yes & \\
\hline 50 & & & yes & & yes & & yes \\
\hline 200 & & & yes & yes & yes & yes & \\
\hline 400 & & yes & & & & & \\
\hline 600 & yes & yes & & & & & \\
\hline 800 & yes & yes & & & & & \\
\hline 1000 & yes & yes & & & & & \\
\hline
\end{tabular}

understood that the models along with produced results are correct. The correctness is judged by verification and validation to which $[14,15]$ assigns the following meanings: verification - to ensure that the computer program of the computerized model and its implementation are correct, validation - confirmation that the computerized model within its domain of applicability possesses a satisfactory range of accuracy consistent with the intended application of the model. In the context of FEM crash test simulation, it is worth noting that the model ought to be developed for a specific application and its validity determined with respect to that purpose. This is extremely important when the individual exploiting the code uses open-source models as in the instance of automobile models available for the Ls-Dyna system. In view of the above definitions, it cannot be assumed that a given model is exactly the one needed for the purpose of a given crash test. This is the purpose of the process known [14] as conceptual model validation whose aim is to determine if the model representation of the problem (e.g. crash test) is correct. This may involve, for instance, an analysis of the boundary conditions for posts that may be assumed as springs or elasto-plastic solids. Having established that it is necessary to conduct a computerized model verification to establish if the computer programming and implementation are correct requires, for instance, running convergence analysis, evaluation of finite element properties, or evaluation of specific functions of the FEM platform used (e.g. hourglass control). Finally, the results undergo operational validation which determines if the model's output behaviour has sufficient accuracy for its intended purpose. As an example, the assessment of the overall deformation of the barrier in comparison with a field test may be conducted. 


\subsection{EXPLICIT DYNAMICS ALGORITHM}

The Ls-Dyna system uses a special form of the central difference method $[16,17,18]$ with a variable time step. At time $t_{n}$ the equation of motion reads

$$
\mathbf{M} \ddot{\mathbf{x}}^{n}=\mathbf{r}^{n}-\mathbf{f}^{n}-\mathbf{h}^{n} .
$$

Here $\mathbf{M}=\operatorname{diag}\left[m_{i i}\right]$ is the diagonal global mass matrix, $\mathbf{r}^{n}$ denotes the vector of external loads, $\mathbf{f}^{n}=\mathbf{f}_{i n t}^{n}\left(\mathbf{x}^{n}\right)-\mathbf{C} \dot{\mathbf{x}}^{n}$ is the vector of internal loads and damping, and $\mathbf{h}^{n}$ denotes a vector of some kind of force resulting from hourglass control. Standard notation is assumed where a superposed dot denotes time derivatives. To update velocity vector $\dot{\mathbf{x}}$ and acceleration vector $\ddot{\mathbf{x}}$, the following formulas are used

$$
\begin{gathered}
\ddot{\mathbf{x}}^{n}=\mathbf{M}^{-1}\left(\mathbf{r}^{n}-\mathbf{f}^{n}-\mathbf{h}^{n}\right), \\
\dot{\mathbf{x}}^{n+\frac{1}{2}}=\dot{\mathbf{x}}^{n-\frac{1}{2}}+\Delta t_{n} \ddot{\mathbf{x}}^{n}, \\
\mathbf{x}^{n+1}=\mathbf{x}^{n}+\Delta t_{n+\frac{1}{2}} \dot{\mathbf{x}}^{n+\frac{1}{2}}, \quad \Delta t_{n+\frac{1}{2}}=\frac{1}{2}\left(\Delta t_{n}+\Delta t_{n+1}\right) .
\end{gathered}
$$

Given the diagonal form of $\mathbf{M}$, the above equations constitute a fast time marching scheme as the decomposition of $\mathbf{M}$ is not necessary. Yet the algorithm is conditionally stable thus requiring the selection of a stable time step. This time step is evaluated through the relation

$$
\Delta t=\alpha \Delta t_{c r t}
$$

with $\alpha$ as the Courant number. In [16] the following range $0,8 \leq \alpha \leq 0,9$ is specified. A critical time step $\Delta t_{c r t}$ in (5) is determined on an element-by-element basis depending on the spatial dimensions of the element i.e. (1D, 2D, 3D) and material properties expressed in terms of the velocity of a wave. That is

$$
\Delta t=\alpha \Delta t_{c r t} \leq \min _{e} \frac{l_{e}}{c_{e}}
$$

Here $l_{e}$ is the characteristic length of an element and $c_{e}$ the dilatational wave velocity. Condition (6) is checked at time $n$ to compute the time step for next time instance

$$
\Delta t^{n+1}=\alpha \min \left\{\Delta t_{1}, \Delta t_{2}, \Delta t_{3}, \ldots, \Delta t_{N}\right\}
$$




\subsection{NUMERICAL MODEL SUMMARY}

A general view of a crash test scene is shown in Fig. 1. The numbering of the posts (the distance between them is equal to $2000 \mathrm{~mm}$ ), velocity, angle, and exact point of impact are presented. All parameters fulfill the requirements for a standard TB51 test [12]. The numerical model consists of two submodels. The coach model was developed by the Norwegian Public Road Administration (www.vegvesen.no) and is available free of charge. The barrier model is based on the real-life ORSTA bridge barrier [13] with some minor simplifications. In an earlier paper [19] some results concerning the verification and validation of the numerical model were addressed. It should be noted that the present study has not been carried out in a real scale test, therefore the current results are only presumptions of actual behavior.

The numerical model consists of 671511 finite elements; mostly Belytschko-Tsay 4-noded and uniformly reduced integration shell elements. Hourglass control type 4 is applied with a parameter $q_{H}=0.03$.

\section{SIMULATION RESULTS AND DISCUSSION}

A total of 7 numerical simulations were carried out with varying distances between the curb and the barrier, denoted by $a$ (see Fig. 1). In each case the same point of impact was selected, between posts no. 8 and no. 9. The obtained results support the conclusion that the placement of the barrier relative to the curb does not significantly influence the value of the working width of the barrier. In the case of $a=0$, the bus correctly redirects itself back onto the road. Once the front of the bus collides with the barrier, the back of the vehicle collides with the barrier twice (i.e. the first collision was observed in the vicinity of post no. 8 and the second near post no. 12). In this case, the calculated value of the working width was the same regardless of a front/back collision.

In the case of $a \in\{50 ; 200 ; 400\}$, a similar crash test path was observed. For $a=400$ a great lateral tilt of the bus was observed. In the case of $a \in\{600 ; 800 ; 1000\}$, the bus was lifted upwards by the barrier structure. As a consequence of a large $a$ value, the front wheel is on the curb instead of on the road. Therefore, the lower part of the bus's bumper collides with the barrier allowing the wheel to run over the post. The damage of the vehicle chassis and the barrier are visible, see Fig. 2.

The lowest value of the working width was calculated for $a=600 \mathrm{~mm}$ and the highest for $a=1000 \mathrm{~mm}$. When the barrier is close to the curb, the working width is influenced by the front-end collision and the post most damaged by impact is post no. 10. When the distance between the curb 
and the barrier is increased, the collision in the back end of the bus is the decisive factor influencing working width - since it's the secondary collision of the deformed barrier. In both cases the element connecting the guardrail with the post suffered damage. Results obtained in numerical runs are shown in Table 3. The time instance in which working width was calculated is shown in Fig. 3.

\section{Conclusions}

The numerical results obtained show that the placement of the curb relative to the guardrail does not contribute significantly to the value of the working width of the barrier. It does however have an impact on the course of the crash event itself: the motion of the vehicle and the deformation of the barrier. In the simulations it can be seen that that when the studied distance was minor, the barrier redirected the bus back onto the road, though when the distance was assumed as further, the vehicle's wheels were lifted by the curb and remained on it.

a)

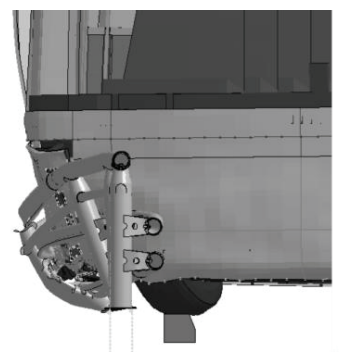

c)

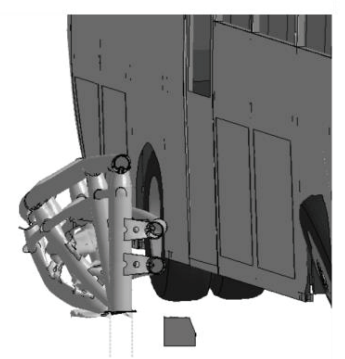

b)

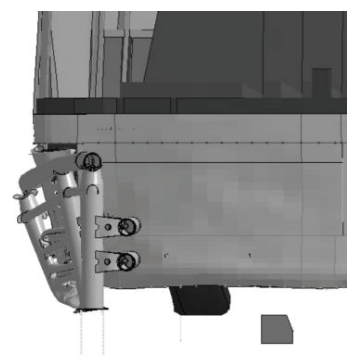

d)

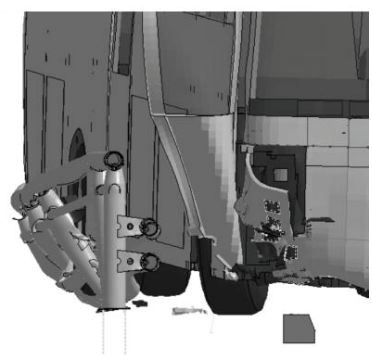

Fig. 2. Front wheel at the curb a) $a=200 \mathrm{~mm} \mathrm{~b}) a=1000 \mathrm{~mm}$, rear wheel at the curb c) $a=200 \mathrm{~mm}$ d) $a=1000 \mathrm{~mm}$. 


\section{ACKNOWLEDGEMENTS}

Research is funded by the Development of Road Innovation research program, project RID 3A (contract number DZP/RID-I-67/13/NCBR/2016), and ordered by: The National Centre for Research and Development (NCBiR) and the General Director for National Roads and Motorways (GDDKiA).

Calculations have been carried out at the Academic Computer Center in Gdańsk, Gdańsk University of Technology. The Coach model was developed by the Norwegian Public Road Administration (www.vegvesen.no).

Table 3. Simulation results - working width and barrier damage

\begin{tabular}{|c|c|c|c|c|c|}
\hline $\begin{array}{c}\text { Barrier face-to- } \\
\text { curb distance } a \\
{[\mathrm{~mm}]}\end{array}$ & $\begin{array}{c}\text { Working } \\
\text { width } W_{\mathrm{N}}[\mathrm{m}]\end{array}$ & $\begin{array}{c}\text { Working } \\
\text { width class }\end{array}$ & $\begin{array}{c}\text { Impact of } \\
\text { front } / \text { rear of bus } \\
\text { then } W_{\mathrm{N}} \text { is } \\
\text { measured }\end{array}$ & Barrier part affected $W_{N}$ & $\begin{array}{l}\text { Posts needing } \\
\text { replacement }\end{array}$ \\
\hline 0 & 0,98 & $W 3$ & front/back & post no. 10 & 5 (from 8 to 12 ) \\
\hline 50 & 0,97 & $W 3$ & front & post no. 10 & 4 (from 8 to 11 ) \\
\hline 200 & 0,95 & $W 3$ & front & post no. 10 & 5 (from 8 to 12 ) \\
\hline 400 & 0,95 & $W 3$ & front & $\begin{array}{c}\text { Top hand rail between } \\
\text { post } 10 \text { and } 11\end{array}$ & 5 (from 8 to 12 ) \\
\hline 600 & 0,94 & $W 3$ & front & post no. 10 & 5 (from 8 to 12 ) \\
\hline 800 & 0,95 & $W 3$ & back & $\begin{array}{c}\text { Top hand rail between } \\
\text { post } 11 \text { and } 12\end{array}$ & 6 (from 8 to 13 ) \\
\hline 1000 & 0,99 & $W 3$ & back & $\begin{array}{l}\text { Top hand rail between } \\
\text { post } 10 \text { and } 11\end{array}$ & 6 (from 8 to 13 ) \\
\hline
\end{tabular}

a)

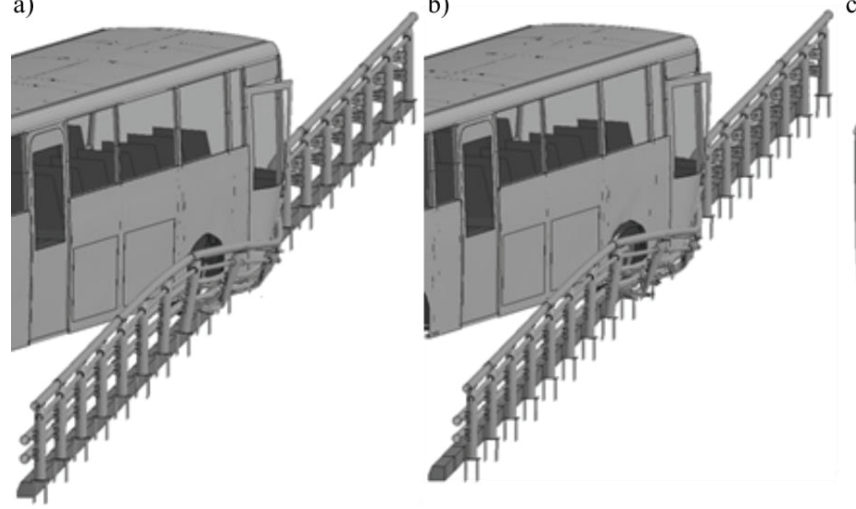

c)

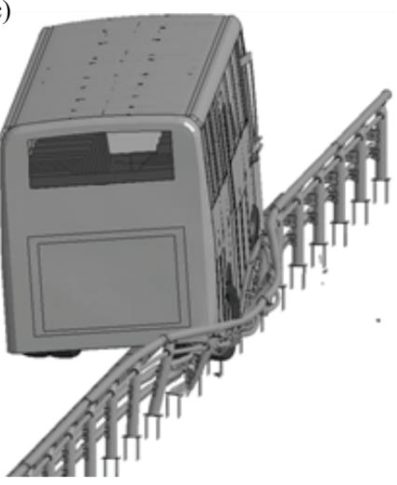

Fig. 3. Time instance at which working width was obtained a) $a=0 \mathrm{~mm}$ b) $a=200 \mathrm{~mm}$

$$
\text { c) } a=800 \mathrm{~mm}
$$




\section{REFERENCES}

1. L. Kwaśniewski, H. Li, R. Nimbalkar, J. Wekezer „Crashworthiness assessment of a paratransit bus” International Journal of Impact Engineering 32: 883-888, 2006.

2. L. Kwaśniewski, C. Bojanowski, J. Siervogel, J.W. Wekezer, K. Cichocki "Crash and safety assessment program for paratransit buses", International Journal of Impact Engineering 36: 235-42, 2009.

3. K. Jamroz, S. Burzyński, W. Witkowski, K. Wilde, G. Bagiński „Numerical methods for the assessment of bridge safety barriers". Advances In Mechanics: Theoretical, Computational And Interdisciplinary Issues: 231234, 2016.

4. M. Klasztorny, K. Zielonka, D.B. Nycz, P. Posuniak "Experimental Verification of Simulation of TB32 Crash Test for SP-05/2 Road Safety Barrier on Horizontal Concave Arc.” Journal of Civil Engineering, Environment and Architecture 64: 107-118, 2017.

5. GDDKiA „Wytyczne stosowania drogowych barier ochronnych na drogach krajowych”. Warsaw, 2010.

6. Dz.U.2000.63.735 „Rozporządzenie Ministra Transportu i Gospodarki Morskiej z dnia 30 maja 2000 r. w sprawie warunków technicznych, jakim powinny odpowiadać drogowe obiekty inżynierskie i ich usytuowanie."

7. ZDW w Katowicach, „Wytyczne projektowe stosowania drogowych barier ochronnych na drogach wojewódzkich”. Katowice, 2012.

8. Ministerstvo dopravy „Odbor silniční infrastruktury. Svodidla na pozemních komunikacích”, Dopravoprojekt Brno, 2010.

9. TRB, "NCHRP Report 537. Recommended Guidelines for Curb and Curb-Barrier Installations." Washington, D.C. 2005.

10. Austroads. "Guide to road design part 6: Roadside design, safety and barriers." Sydney 2015.

11. Norwegian Public Roads Administration. "Vehicle Restraint Systems and Roadside Areas." Oslo 2014.

12. PE-EN 1317-1/8: 2010, Systemy ograniczające drogę - Część 1-8.

13. Technical Approval, RaRRI, nr AT/2006-03-2011, "Stalowe barieroporęcze i balustrady ORSTA do stosowania na obiektach mostowych", Warsaw, 2006.

14. R.G. Sargent, "Verification and Validation of Simulation Models", Proc. 2007 Winter Simul. Conf. 124-137, 2007.

15. L. Kwaśniewski, "On practical problems with verification and validation of computational models", Archives of Civil Engineering, 55 (3): 323-346, 2009.

16. T. Belytschko, W.K. Liu, B. Moran, K.I. Elkhodary, "Nonlinear finite elements for continua and structures" Wiley, 2014.

17. J. Hallquist, "Ls-Dyna, Theory Manual” 2006.

18. T.J.R. Hughes, "The Finite Element Method: linear static and dynamics finite element analysis." Mineola, New York, Dover Publications Inc., 2000.

19. K. Wilde et al., "Numerical simulations of bus crash-test with barrier and truss supporting structure." Journal of Civil Engineering, Environment and Architecture 63: 455-467, 2016.

\section{LIST OF FIGURES AND TABLES:}

Tab. 1. Levels of working width.

Tab. 1. Klasy poziomów szerokości współpracującej

Fig. 1. General view of the crash test, aerial view of the impact point, parameter $a$ definition.

Rys. 1. Widok ogólny testu zderzeniowego, widok z góry na miejsce uderzenia, definicja parametru $a$.

Tab. 2. Analyzed values of a and compliance to recommendations of each guideline.

Tab. 2. Rozpatrywane wartości a oraz informacja o wypełnieniu rekomendacji poszczególnych rozporządzeń.

Fig, 2. Front wheel at the curb a) $a=200 \mathrm{~mm}$ b) $a=1000 \mathrm{~mm}$, rear wheel at the curb c) $a=200 \mathrm{~mm}$ d) $a=1000 \mathrm{~mm}$. 
Rys. Przednie koło na krawężniku a) $a=200 \mathrm{~mm}$ b) $a=1000 \mathrm{~mm}$, tylne koło na krawężniku c) $a=200 \mathrm{~mm}$ d) $a=1000 \mathrm{~mm}$.

Tab. 3. Simulation results - working width and barrier damage

Tab.3. Wyniki symulacji - szerokość pracująca oraz zniszczenie bariery

Fig. 3. View at moment when working width is reached a) $a=0 \mathrm{~mm}$ b) $a=200 \mathrm{~mm}$ c) $a=800 \mathrm{~mm}$

Rys. 3. Widok w chwili uzyskania szerokości pracującej a) $a=0 \mathrm{~mm}$ b) $a=200 \mathrm{~mm}$ c) $a=800 \mathrm{~mm}$

Received: 31.01.2017

Revised: 13.05.2017 


\section{WPLYW ODLEGLOŚCI LICA BARIERY OD KRAWĘŻNIKA W SYMULACJI TESTU ZDERZENIOWEGO TB51 BARIEROPORECZY MOSTOWEJ.}

Keywords: test zderzeniowy, barieroporęcz mostowa, autobus, symulacja, LS-DYNA

\section{SUMMARY :}

Kwestia bezpieczeństwa ruchu drogowego w Polsce w ostatnim czasie stała się przedmiotem wielu programów badawczych. Narodowe Centrum Badań i Rozwoju (NCBiR) wraz z Generalną Dyrekcją Dróg Krajowych i Autostrad (GDDKiA) zainicjowało program badawczy Rozwój Innowacji Drogowych (RID), którego celem jest m.in. kompleksowa analiza systemów powstrzymujących pojazd zainstalowanych na drogach i obiektach inżynierskich.

W artykule badano wpływ usytuowania bariery mostowej względem krawężnika na wartość szerokości pracującej, czyli odległości pomiędzy powierzchnią czołową bariery od strony ruchu a maksymalnym bocznym dynamicznym położeniem jakiejkolwiek części bariery.

W aktualnie obowiązujących w Polsce wytycznych dla dróg krajowych brak jest zapisów na temat zalecanej odległości krawężnika od lica bariery, występują jedynie zapisy dotyczące samych krawężników. Przeanalizowano również wytyczne Zarządu Dróg Wojewódzkich w Katowicach. Na podstawie analizy wybranych zagranicznych wytycznych dla urządzeń brd stwierdzono, że zalecana odległość lica bariery od krawężnika jest zmienna w różnych krajach.

W celu określenia wpływu usytuowania bariery względem krawężnika na wartość szerokości pracującej przeprowadzono 7 symulacji numerycznych testu zderzeniowego TB51, w którym autobus o masie 13 ton uderza w barierę mostową ORSTA z prędkością $70 \mathrm{~km} / \mathrm{h}$ pod kątem $20^{\circ}$. Dla wybranych wartości odległości lica bariery od krawężnika sprawdzono zgodność z obowiązującymi wytycznymi.

Symulacje numeryczne przy wykorzystaniu Metody Elementów Skończonych są obecnie bardzo popularne. Poprawność modelu należy ocenić w procesie weryfikacji i walidacji. Weryfikacja ma na celu zapewnienie, że założenia formalne dla modelu numerycznego oraz jego implementacja są poprawne. Walidacja to potwierdzenie, że model komputerowy w swoim obszarze stosowania posiada akceptowalny zakres dokładności, który jest zgodny z zamierzonym zastosowaniem modelu. Należy zaznaczyć, że modele numeryczne tworzone są dla konkretnego przypadku i dla niego przeprowadza się proces walidacji. Należy więc zwrócić szczególną uwagę przy korzystaniu z ogólnodostępnych w Internecie modeli, np. modeli pojazdów. Symulacje testów zderzeniowych przeprowadzono wykorzystując program Ls-Dyna. W tym programie całkowanie równania ruchu odbywa się metodą typu explicit (metoda jawna). Model numeryczny składa się z 671511 elementów skończonych. Model uwzględnia kontrolę form pasożytniczych w elementach z całkowaniem zredukowanym (hourglass control).

W każdym teście bariera wyprowadziła autobus na tor ruchu zbliżony do równoległego. Na podstawie uzyskanych wyników stwierdzono, że usytuowanie bariery względem krawężnika w niewielkim stopniu wpływa na wartość szerokości pracującej. Wpływa natomiast znacznie na przebieg zderzenia, w tym na ruch pojazdu oraz wielkość zniszczeń autobusu i bariery. W przypadku bariery usytuowanej blisko krawężnika, autobus uderza w barierę i zostaje poprawnie wyprowadzony na drogę. Gdy bariera ochronna jest znacznie oddalona od krawężnika, przednie koło autobusu w momencie uderzenia jest już na krawężniku, w wyniku czego autobus uderza w barierę niższą częścią zderzaka, najeżdżając przy tym znacznie na barierę. Skutkuje to większymi uszkodzeniami bariery i pojazdu niż dla przypadku, gdy bariera jest blisko krawężnika. Ponadto przednie koło autobusu po uderzeniu zostaje na krawężniku. Gdy bariera jest blisko krawężnika, o szerokości pracującej decyduje pierwsza faza zderzenia (uderza przód autobusu). 
W przypadku znacznej odległości bariery od krawężnika o szerokości pracującej zdecydowało uderzenie wtórne tyłu autobusu, w miejsca już zdeformowane w wyniku uderzenia jego przodu.

Praca została wykonana w ramach programu Rozwój Innowacji Drogowych, projekt RID 3A. Obliczenia wykonano na komputerach Centrum Informatycznego Trójmiejskiej Sieci Komputerowej. Model autobusu został opracowany przez Norweską Administrację Dróg Publicznych. 